\title{
THE FREQUENCY IN JAPAN OF CARRIERS OF THE RARE "RECESSIVE" GENE CAUSING ACATALASEMIA
}

\author{
By HOWARD B. HAMILTON, JAMES V. NEEL, THOMAS Y. KOBARA AND \\ KYOKO OZAKI \\ (From the Atomic Bomb Casualty Commission, Hiroshima-Nagasaki, Japan,* and the Depart- \\ ment of Human Genetics, University of Michigan Medical School, \\ Ann Arbor, Mich.)
}

(Submitted for publication June 19, 1961 ; accepted August 30, 1961)

Although it is increasingly recognized that many rare recessive genes have effects in the heterozygous state which can be detected by suitable laboratory tests, with the implication that such genes may make a significant contribution to subclinical departures from health, there is a real paucity of knowledge concerning the actual distribution in populations of such heterozygotes. Until now it has not been possible to study the distribution of heterozygotes for a rare "recessive" gene with a simple, quick, and accurate method suitable for survey purposes. It will be the object of this paper to describe such a method for detecting the heterozygous carriers of a particular rare "recessive" gene. Survey data will be presented indicating significant local variations in gene frequency. The implications of such variations for certain basic genetic problems will be briefly explored.

The trait in question is acatalasemia, a recessively inherited condition characterized by the absence of detectable tissue catalase activity (1). Heterozygotes for this gene have been shown to exhibit approximately half-normal values of catalase activity (2). In a previous paper, it was noted that the application of standard genetic formulae led to an estimate of 0.003 for $q$, the frequency of the gene responsible for the trait, from which the frequency of homozygotes was calculated to be 0.00002 , and of heterozygotes, 0.006 ; i.e., 2 and 600 per 100,000 Japanese, respectively (3). The many assumptions which went into these calculations were discussed briefly, with the statement that in general the computations were of such a

* The Commission is a field research agency of the National Academy of Sciences-National Research Council, with financial support from the U. S. Atomic Energy Commission, and is administered in cooperation with the National Institute of Health of the Japanese Ministry of Health and Welfare. nature as to result in inflated estimates of the gene frequency, and it was pointed out that the true gene frequency might well be of the order of 0.0015 . It is now possible to pursue this point further.

\section{METHODS OF STUDY}

\section{A. Composition of the population sample}

Screening for hypocatalasemia was performed on blood samples received in the Clinical Laboratories of the Atomic Bomb Casualty Commission (ABCC) in Hiroshima and Nagasaki. Bloods were derived from three sources: 1) radiation-exposed and nonexposed individuals, who are voluntarily participating in the ABCC Adult Health Study ${ }^{1}(4)$; 2) children seen in the Child Health Study at ABCC (5); and 3) "referrals" of blood specimens to the ABCC by local practitioners, where blood only was received with a request for laboratory determinations. The third group constituted less than 5 per cent of the total number of specimens examined; as far as is known, catalase abnormalities never formed the basis for referral. Between 30 and 60 samples were screened daily in Hiroshima and approximately one-third that number in Nagasaki over a period of about 15 months. No attempt was made at a rigorous exclusion of related individuals, but from the method of selection, it seems unlikely that related individuals (parent-offspring or sibling pairs) constituted more than 15 per cent of the sample. Blood specimens that were positive to the screening test were subjected to the more precise assay for erythrocyte catalase activity, as described below.

\section{B. Assay methods}

1. Screening method. Two $\mathrm{ml}$ of blood was transferred to $20 \mathrm{ml}$ of tap water, with care taken to wipe the outside of the pipet and flush it with the diluent. After gentle mixing, $1 \mathrm{ml}$ of this solution was immediately pipetted into $5.0 \mathrm{ml}$ of $0.01 \mathrm{~N}$ hydrogen peroxide in 0.01 $\mathrm{M}$ phosphate buffer, $\mathrm{pH} 6.8$. After exactly 60 seconds, $2 \mathrm{ml}$ of $2 \mathrm{~N}$ sulfuric acid was added, followed by $7 \mathrm{ml}$ of

\footnotetext{
${ }^{1}$ Since it has been found that there is no difference between erythrocyte catalase activity among exposed and nonexposed individuals, possible radiation effects need not be considered (3).
} 
$0.005 \mathrm{M}$ potassium permanganate. The latter solution may be added to a row of tubes at any convenient time after addition of the acid. If a pink color persists after addition of the permanganate, catalase is present; if the solution remains colorless, catalase is either absent or in low concentration, provided the hemoglobin is within normal limits.

This test is based on two premises: 1) That a given amount of catalase, in a given time interval, decomposes a fixed amount of hydrogen peroxide, the amount remaining in effect being measured by titration with permanganate. The concentration of permanganate chosen was such that only individuals with catalase activity less than 3 standard deviations below the mean catalase activity of a control population would show a positive reaction. 2) This in turn is based on the assumption that the hemoglobin in the blood sample is within normal limits, since it has been shown that there is a linear relationship between erythrocyte catalase activity and hemoglobin concentration (3).

Thus, false positive results are to be expected in those instances where the hemoglobin concentration is low. Because this is primarily a screening test, adjusting the hemoglobin concentration has of necessity been omitted, but the test has been designed so that in the majority of instances only blood samples with a hemoglobin of less than $7.5 \mathrm{~g}$ per cent will give a false positive result. However, since hypocatalasemia is not necessarily ruled out in the presence of anemia, a precise assay for catalase activity must be performed whenever the screening test is positive.

In this study it was customary to withdraw the 2-ml sample from a tube of heparinized or citrated venous blood. However, the method is equally applicable to fresh blood, drawn from a finger or earlobe prick into a hemoglobin pipet and immediately diluted with tap water as described. Further, if it is inconvenient to carry all the reagents into the field, a heparinized pipet may be used, and the blood transported to the laboratory for the screening test. However, care should be taken to avoid unduly long intervals between obtaining the blood and screening, unless the sample is refrigerated. Further, the latter method suffers from the disadvantage that in the case of positive results, where the precise assay becomes necessary, a second sample of blood must be obtained at a later time.

2. Assay for erythrocyte catalase activity. The method for determining erythrocyte catalase activity ( $\mathrm{K}_{\text {eat }}$ activity) has already been described (3). A preliminary attempt was made to determine the frequency with which false positive (positive screen with normal $K_{\text {eat }}$ ) and false negative results (negative screen with low $K_{\text {eat }}$ ) occurred. In a series of 120 "blind" tests, in which both the screening and $K_{c a t}$ assay were performed on individual samples, there were no instances of false negative results, but false positive results did occur, either because of a low hemoglobin level, as discussed above, or a combination of a $\mathrm{K}_{\mathrm{cat}}$ value at the lower limit of normal and a somewhat lowered hemoglobin level. In the total survey series, about 1 per cent of the screening
TABLE I

The frequency of hypocatalasemia in six different surveys

\begin{tabular}{ccccc}
\hline \hline Population & Survey & $\begin{array}{c}\text { No. } \\
\text { examined }\end{array}$ & $\begin{array}{c}\text { No. } \\
\text { hypo- } \\
\text { catal- } \\
\text { asemic }\end{array}$ & $\begin{array}{c}\text { Frequency } \\
\text { of hypo- } \\
\text { catalase- } \\
\text { mia }\end{array}$ \\
\hline $\begin{array}{c}\text { Hiroshima } \\
\text { Japanese } \\
\text { Nagasaki } \\
\text { Japanese }\end{array}$ & Present study & 10,679 & $10^{*}$ & 0.000936 \\
$\begin{array}{c}\text { Okayama } \\
\text { Japanese } \\
\text { Nagano } \\
\text { Japanese }\end{array}$ & Reference 7 & 1,500 & 0 & 0.000000 \\
$\begin{array}{c}\text { Shimane } \\
\text { Japanese }\end{array}$ & Reference 7 & 1,975 & 30 & 0.015190 \\
$\begin{array}{c}\text { Okayama } \\
\text { Koreans }\end{array}$ & Reference 7 & 618 & 6 & 0.009709 \\
\hline
\end{tabular}

* Includes one mother-daughter pair.

$\dagger$ Includes one pair of siblings.

tests gave false positive results. It would thus appear that in surveying a large population, false positive results can be minimized by determination of the hemoglobin values and performance of the $\mathrm{K}_{\mathrm{cat}}$ assay, whereas false negative results (e.g., missed hypocatalasemics ) apparently occur rarely, if at all.

\section{Family studies}

In all instances in which a positive screening test followed by a $\mathrm{K}_{\text {cat }}$ assay revealed the presence of a hypocatalasemic individual, a second sample of fresh blood was obtained at a later date and $\mathrm{K}_{\mathrm{cat}}$ activity redetermined. In every case, the second result confirmed the first. At this second visit, a careful pedigree was obtained from the proband; subsequently, blood samples were obtained from as many other members of the family as possible. In this way, individuals from 10 families were studied in detail with respect to $K_{\text {cat }}$ values.

\section{RESULTS}

Table I summarizes the survey findings in Hiroshima and Nagasaki. The probability of as great or a greater difference between the two cities if the expectation for both is the same, as evaluated by the exact method for $2 \times 2$ tables (6), is 0.28 , clearly nonsignificant. Figure 1 and Table II present the data obtained in studies on the kindreds of the 11 hypocatalasemic subjects encountered in the course of the survey. The column labeled "pedigree position" refers to the position of each individual in the pedigrees of the 10 kindreds concerned, as shown in Figure $1 .^{2}$

2 Although 11 hypocatalasemics were encountered, 2 were related as mother and daughter, so that only 10 kindreds were represented. 


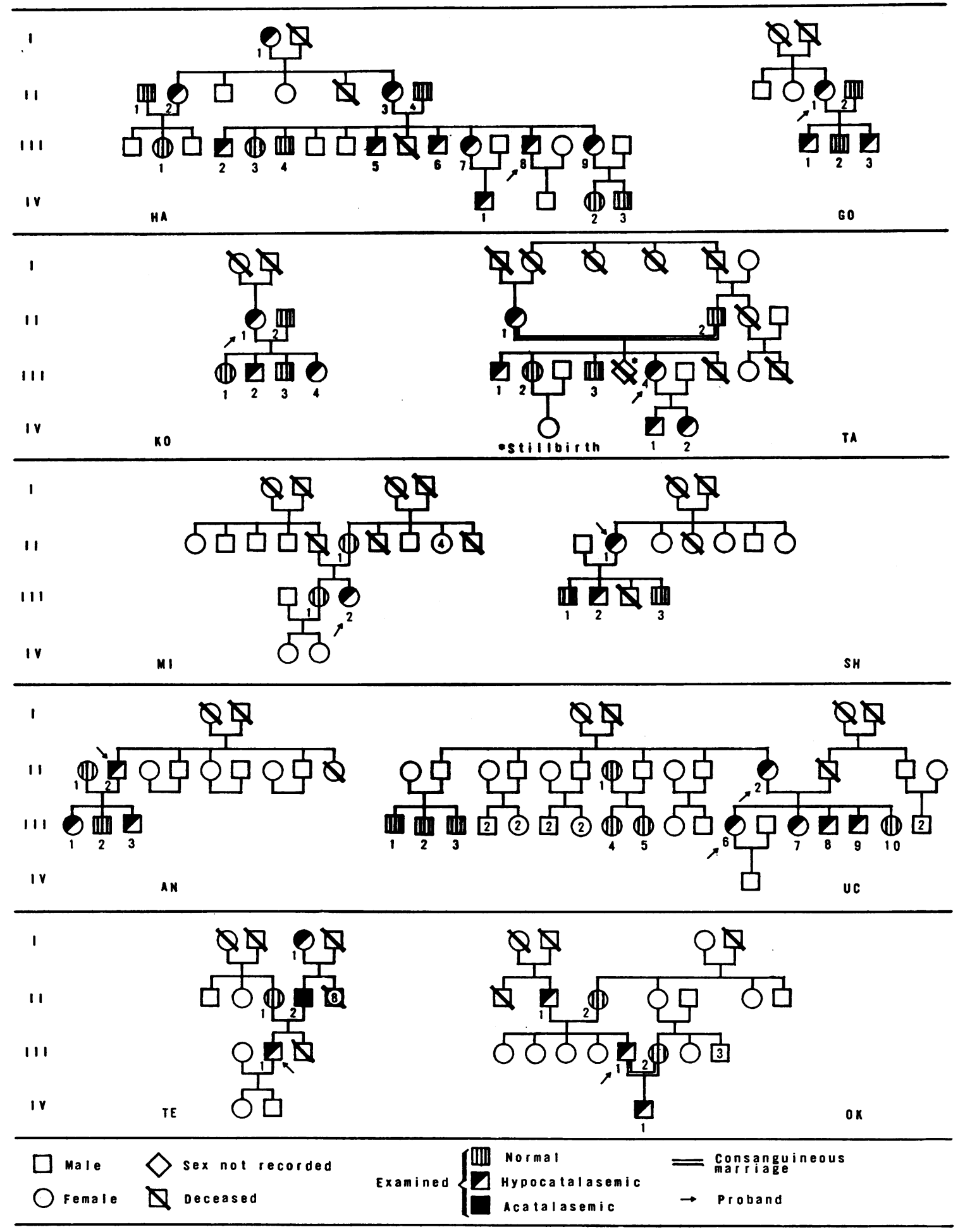

Fig. 1. The Results of FAMILy Studies on Individuals found to Have hypocatalasemia IN THE COURSE OF THIS SURVEY. 
In every kindred studied except one, other members of the kindred were found to be carriers; in this exceptional kindred, only a single parent and one sibling were available for study.

Means, ranges, and standard deviations of $K_{\text {cat }}$ values for normal and hypocatalasemic subjects in this study are compared in Table III with those previously reported (3). In the previous study, a significant difference was noted between the mean for normal control determinations performed on subjects being studied at the ABCC and the mean for presumed normal subjects in families with acatalasemic members. This was attributed to the fact that it was often necessary to store the specimens from the latter group for several days before it was feasible to perform catalase deter- minations, presumably with some loss of catalase activity. In the present study, in which it was possible to perform the determinations almost immediately after the blood was drawn, the normal values correspond very well with $\mathrm{ABCC}$ clinic control values, thus corroborating the suggestion of loss of catalase activity with storage.

The present data confirm in all respects the previously advanced hypothesis that hypocatalasemia and acatalasemia are related as heterozygote and homozygote and, further, demonstrate that the present screening technique is highly efficient in the recognition of hypocatalasemia. Japanese investigators are now conducting surveys at widely scattered points in Japan. The most advanced of these surveys are those of Takahara (7), some of

TABLE II

$K_{\text {cat }}$ values for members of kindreds in which hypocatalasemia occurs

\begin{tabular}{|c|c|c|c|c|c|c|c|c|c|}
\hline Family & $\begin{array}{c}\text { Pedigree } \\
\text { position }\end{array}$ & Sex & Age & $\mathrm{K}_{\text {oat }}$ & Family & $\begin{array}{c}\text { Pedigree } \\
\text { position }\end{array}$ & Sex & Age & $\mathbf{K}_{\text {cat }}$ \\
\hline \multirow{18}{*}{$\mathrm{HA}$} & I-1 & $\mathrm{F}$ & 76 & 2.64 & \multirow{5}{*}{ GO } & II-1 & $\mathrm{F}$ & 42 & $2.43^{*}$ \\
\hline & II-1 & $\mathrm{M}$ & 54 & 5.75 & & II -2 & $\mathrm{M}$ & 45 & 5.55 \\
\hline & II -2 & $\mathrm{~F}$ & 50 & 2.32 & & III-1 & $\mathrm{M}$ & 10 & 2.54 \\
\hline & II -3 & $\mathrm{~F}$ & 53 & 2.22 & & III-2 & M & $\begin{array}{l}10 \\
16\end{array}$ & $\begin{array}{l}2.04 \\
5.15\end{array}$ \\
\hline & II-4 & $\mathrm{M}$ & 55 & 5.10 & & \multirow[t]{2}{*}{ III-3 } & \multirow[t]{2}{*}{$\mathrm{M}$} & \multirow[t]{2}{*}{19} & \multirow[t]{2}{*}{2.52} \\
\hline & III-1 & $\mathrm{F}$ & 22 & 5.26 & \multirow{9}{*}{$\mathrm{TA}$} & & & & \\
\hline & III-2 & $\mathrm{M}$ & 12 & 2.44 & & II-1 & $\mathrm{F}$ & 61 & 2.71 \\
\hline & III-3 & $\mathrm{F}$ & 14 & 5.55 & & II-2 & $\mathrm{M}$ & 66 & 3.92 \\
\hline & III -4 & $\mathrm{M}$ & 15 & 4.47 & & III-1 & $\mathbf{M}$ & 25 & 1.94 \\
\hline & III-5 & $\mathrm{M}$ & 21 & 2.49 & & II I-2 & $\mathrm{F}$ & 26 & 5.79 \\
\hline & III-6 & $\mathrm{M}$ & 25 & 2.08 & & III-3 & $\mathrm{M}$ & 29 & 5.40 \\
\hline & III-7 & $\mathrm{F}$ & 27 & 2.53 & & III-4 & $\mathrm{F}$ & 38 & $2.47^{*}$ \\
\hline & III-8 & $\mathrm{M}$ & 28 & $2.12^{*}$ & & IV-1 & $\mathrm{M}$ & 5 & 2.54 \\
\hline & III-9 & $\mathrm{F}$ & 29 & 2.23 & & IV-2 & $\mathrm{F}$ & 8 & 2.47 \\
\hline & IV-1 & $\mathbf{M}$ & 2 & 2.36 & \multirow{7}{*}{$\mathrm{SH}$} & \multirow{7}{*}{$\begin{array}{l}\text { II I-1 } \\
\text { III-1 } \\
\text { III-2 } \\
\text { III-3 }\end{array}$} & \multirow{4}{*}{$\begin{array}{l}\mathrm{F} \\
\mathrm{M} \\
\mathrm{M}\end{array}$} & \multirow{4}{*}{$\begin{array}{l}51 \\
16 \\
18\end{array}$} & \multirow{6}{*}{$\begin{array}{l}2.23^{*} \\
5.11 \\
2.95 \\
5.36\end{array}$} \\
\hline & IV -2 & $\mathrm{~F}$ & 3 & 4.40 & & & & & \\
\hline & IV -3 & $\mathrm{M}$ & 5 & 5.55 & & & & & \\
\hline & & & & & & & & & \\
\hline \multirow{6}{*}{$\mathrm{KO}$} & II-1 & $\mathrm{F}$ & 44 & $2.14^{*}$ & & & $\mathbf{M}$ & 23 & \\
\hline & II-2 & $\mathrm{M}$ & 49 & 6.28 & & & & & \\
\hline & III-1 & $\mathrm{F}$ & 7 & 5.66 & & & \multirow[b]{2}{*}{$F$} & \multirow[b]{2}{*}{38} & \multirow{5}{*}{$\begin{array}{l}5.30 \\
2.73^{*} \\
4.88 \\
5.11\end{array}$} \\
\hline & III-2 & $\mathrm{M}$ & 10 & 2.92 & \multirow{8}{*}{$\mathrm{UC} \dagger$} & \multirow{8}{*}{$\begin{array}{r}\text { II }-1 \\
\text { II-2 } \\
\text { III-1 } \\
\text { III-2 } \\
\text { III-3 } \\
\text { III-4 } \\
\text { III-5 } \\
\text { III-6 }\end{array}$} & & & \\
\hline & III -3 & $\mathbf{M}$ & 12 & 5.71 & & & $\mathrm{~F}$ & 46 & \\
\hline & III -4 & $\mathrm{~F}$ & 20 & 2.93 & & & $\mathbf{M}$ & 22 & \\
\hline & & & & & & & $\mathbf{M}$ & 19 & \\
\hline \multirow{4}{*}{ MI } & II-1 & $\mathrm{F}$ & 67 & 5.30 & & & $\mathrm{M}$ & 12 & 5.16 \\
\hline & III-1 & $\mathrm{F}$ & 40 & 5.11 & & & $\mathrm{~F}$ & 17 & 5.15 \\
\hline & III-2 & $\mathrm{F}$ & 25 & $2.35^{*}$ & & & $\mathrm{~F}$ & 14 & 6.33 \\
\hline & \multirow{6}{*}{$\begin{array}{r}\text { II-1 } \\
\text { II-2 } \\
\text { IIII-1 } \\
\text { III-2 } \\
\text { III-3 }\end{array}$} & & & & & & $\mathrm{F}$ & 26 & $2.66^{*}$ \\
\hline \multirow{5}{*}{$\mathrm{AN}$} & & \multirow{5}{*}{$\begin{array}{l}\mathrm{F} \\
\mathrm{M} \\
\mathrm{F} \\
\mathrm{M} \\
\mathrm{M}\end{array}$} & \multirow{5}{*}{$\begin{array}{r}32 \\
41 \\
11 \\
10 \\
8\end{array}$} & \multirow{5}{*}{$\begin{array}{l}5.05 \\
2.35^{*} \\
2.51 \\
6.25 \\
2.77\end{array}$} & & III-7 & $\mathrm{F}$ & 22 & 2.72 \\
\hline & & & & & & III-8 & $\mathrm{M}$ & 21 & 2.57 \\
\hline & & & & & & III-9 & $\mathbf{M}$ & 19 & 2.98 \\
\hline & & & & & & III-10 & $\mathrm{F}$ & 16 & 4.80 \\
\hline & & & & & & & & & \\
\hline \multirow{4}{*}{ TE } & & & & 283 & & II-1 & $\underset{\mathrm{F}}{\mathrm{M}}$ & $\begin{array}{l}63 \\
59\end{array}$ & 2.21 \\
\hline & II-1 & $\mathbf{F}$ & $\begin{array}{l}80 \\
56\end{array}$ & $\begin{array}{l}2.03 \\
5.73\end{array}$ & OK & III-1 & $\mathrm{M}$ & 35 & $2.37^{*}$ \\
\hline & II-2 & $\mathbf{M}$ & 60 & 0 & & III-2 & $\mathrm{F}$ & 30 & 5.33 \\
\hline & III-1 & $\mathbf{M}$ & 33 & $2.67^{*}$ & & IV -1 & $\mathrm{M}$ & 8 & 2.96 \\
\hline
\end{tabular}

* Proband.

† The two probands, II-2 and III-6, of kindred UC were ascertained independently of each other. 
TABLE III

A comparison of $K_{\text {cat }}$ values in control individuals and in members of kindreds segregating for hypocatalasemia and acatalasemia

\begin{tabular}{|c|c|c|c|c|}
\hline \multirow[b]{2}{*}{ Source and type of patient } & \multirow[b]{2}{*}{ No. } & \multicolumn{3}{|c|}{$\mathrm{K}_{\text {cat }}$ values } \\
\hline & & Mean & SD & Range \\
\hline ABCC Clinic control & 259 & 5.38 & 0.73 & $3.90-7.47$ \\
\hline \multicolumn{5}{|l|}{$\begin{array}{l}\text { Non-acatalasemic members of } \\
\text { kindreds segregating for } \\
\text { acatalasemia (Reference 3): }\end{array}$} \\
\hline $\begin{array}{l}\text { Normal } \\
\text { Hypocatalasemic }\end{array}$ & $\begin{array}{l}55 \\
31\end{array}$ & $\begin{array}{l}4.97 \\
2.17\end{array}$ & $\begin{array}{l}0.61 \\
0.35\end{array}$ & $\begin{array}{l}3.96-6.47 \\
1.48-2.87\end{array}$ \\
\hline \multicolumn{5}{|l|}{$\begin{array}{l}\text { Kindreds found to be segregating } \\
\text { for hypocatalasemia (present } \\
\text { study): }\end{array}$} \\
\hline $\begin{array}{l}\text { Normal } \\
\text { Hypocatalasemic }\end{array}$ & $\begin{array}{l}31 \\
37\end{array}$ & $\begin{array}{l}5.30 \\
2.51\end{array}$ & $\begin{array}{l}0.53 \\
0.27\end{array}$ & $\begin{array}{l}3.92-6.28 \\
1.94-2.98\end{array}$ \\
\hline
\end{tabular}

the results of which have been reproduced in Table I. He has studied three areas, namely, Okayama, a city of some 236,000 individuals situated on the island of Honshu, facing the Inland Sea, and two semi-mountainous regions of central and western Honshu, located in Nagano and Shimane prefectures, respectively, where several sibships with acatalasemic members have been encountered. The figures for Okayama Japanese (college students, 740 ; patients attending an otology clinic, 419 ; and randomly selected adults, 341) are in satisfactory agreement with those for Hiroshima and Nagasaki. The figures for Nagano and Shimane are based on surveys of primary school children from the first through the sixth grades. The sample undoubtedly includes some sibling pairs. Furthermore, consanguinity rates are relatively high in Nagano; Kubota and others (8) reported total values for different localities ranging from 9 to 28 per cent. Although consanguinity rates for Shimane have not been established, on the basis of reports for other widely separated rural areas in Japan (Summary in Reference 9), it is probably safe to assume that the frequency of consanguineous marriages corresponds to that of other similar sections of the country. Thus, it seems quite likely that there is a significantly greater proportion of related individuals in these two samples than in those for the three cities studied thus far. These facts raise some theoretical difficulties in the interpretation of the usual tests for the significance of frequency differences, since a single extended kindred might be contributing most of the affected individuals in Nagano or Shimane. The probability of observing a difference equal to or exceeding that between the combined observations in Hiroshima and Nagasaki and those in Nagano and Shimane (if the expectation for the areas concerned were the same and all observations independent) as computed by any one of several methods, is very low-well beyond the usual significance levels. While allowance for the possible biological relatedness of some of the individuals in the sample would reduce to some degree the apparent significance of the differences, it could scarcely eliminate them. In round terms, the frequency of carriers in the Nagano and Shimane areas is some 10 to 15 times that in Hiroshima and Nagasaki.

The preliminary findings in persons of Korean descent residing in Okayama, also summarized in Table I, are especially interesting. This group, composed of schoolboys from four different districts in Okayama, was surveyed after acatalasemia was recently encountered in three Korean siblings in Tokyo (10). In a previous publication (3) it was argued, from the widespread distribution throughout Japan of the relatively few sibships with acatalasemic members, that the responsible gene was one of considerable antiquity. The demonstration of the gene in Koreans can be regarded as reinforcement for that suggestion, since the principal route by which the Japanese reached their islands appears to have been by way of Korea (11-15), and it seems more likely, in view of the history of Japanese-Korean relationships, that the gene was introduced into Japan by way of Korea than that recent Japanese-Korean contacts have resulted in the introduction of the gene into Korea. On the other hand, the possibility of multiple independent origins of the gene, in both Korea and Japan, cannot be completely disregarded.

\section{DISCUSSION}

Clearly there are significant local variations in Japan in the frequency of heterozygotes for the acatalasemia gene. The concept suggested by these data, of "pockets" wherein certain rare and "pathological" recessive genes are represented by unusually high frequencies, is of course not new (16), but previously the means of directly verifying and quantitating this concept have not been at hand. This demonstration has important implications for the use of certain genetic formulae, 
which are discussed below. In a previous publication, the frequency in Japan of carriers of the gene for acatalasemia was estimated at 0.006 (3). This estimate was based on a formula derived by Dahlberg (17), namely,

$$
q=\frac{c(1-k)}{16 k-15 c-c k}
$$

with the frequency of heterozygotes then calculated from the relationship,

$$
\text { heterozygotes }=2 q(1-q)(1-\alpha)
$$

where $q=$ the frequency of the recessive gene responsible for acatalasemia; $c=$ the proportion of first-cousin marriages among the population as a whole, assumed from previous studies in Japan to be $0.06(18,19) ; k=$ the proportion of firstcousin marriages among the parents of homozygous individuals, assumed from the data on 17 sibships to be 0.59 (3) ; and $\alpha=$ the coefficient of inbreeding for the population, assumed from previous studies to be 0.004 (18).

Kimura (20) has now provided a more general, maximum likelihood-type formula, which has the advantage of utilizing for the estimate all the data available concerning consanguinity in the parents of affected individuals. Kimura has also derived the formula for the variance of the estimate, which was not available for Dahlberg's approach. With this method, substituting values to be found in our previous paper, the gene frequency is estimated at 0.00082 , with a standard error of 0.0053 . Thus, within the range of 1 standard error above and below the estimated gene frequency are to be found values from zero to 0.0061 , the latter corresponding to a carrier frequency of 0.0121 . The estimate has so large an error as to encompass the value obtained with the Dahlberg equation and also both the observed Nagasaki-Hiroshima and the Nagano-Shimane values, even though these latter two values differ significantly from each other. Although, with only 17 sibships on which to base the gene frequency estimate, a large error was to be expected, the actual magnitude of this error is sobering. It is clear that many more data must be collected before it will be possible to test with any precision the degree to which the gene frequencies predicted for various regions in Japan and the total area will depart from the frequencies which can be determined by suitable surveys. At a first approximation, it would appear that at least 100 additional sibships in which acatalasemia is segregating will be necessary to refine the gene frequency estimate to the point where comparisons between observation and expectation become meaningful.

The importance of estimating the frequency of the carriers of a variety of recessive genes is such that a considerable expenditure of effort in pursuing this favorable test situation would be warranted if it promised to yield a critical evaluation of the usefulness of Dahlberg's and Kimura's formulae. However, there is now reason to suspect that human populations depart from the mathematical models on which the formulae are based to an extent which renders a close correspondence between prediction and observation unlikely. The formulae are based on certain rather sweeping assumptions. Although geneticists have recognized for some years that these assumptions involve oversimplifications of highly complex situations (Discussion in $3,17,18,21,22$ ), the use of the formulae was nevertheless justified because, in the case of rare recessive traits, it resulted in an approximation to a figure usually not otherwise available. These assumptions state that:

1) There is a uniform gene frequency throughout the total area under consideration, an assumption whose incorrectness in the case of acatalasemia has already been demonstrated by graphic evidence.

2) The population is in genetic equilibrium; i.e., the balance between mutation, selection, and population structure is such that the gene frequency has stabilized.

3) The population constitutes one interbreeding unit. Patently, two individuals, one from Hokkaido and one from Kyushu, have much less opportunity of marrying than a pair from Honshu, but migration between the hierarchy of "isolates" (or neighborhoods) within "isolates" which comprise a population is assumed to occur at a rate sufficient to result in a satisfactory approximation to the model.

4) The disease is genetically homogeneous; i.e., all affected individuals result from mutation at the same locus, again an assumption that seems untrue for acatalasemia ( 3 and unpublished observations). 
It is clear that we are not yet in a position to judge just how far human populations depart from assumptions 2,3 , and 4 , or the manner in which these departures influence mathematical prediction. There are indications, however, that the departures may be very considerable. On the other hand, the data of this paper, plus the findings of Takahara, do give us rather graphic insight into the departures which may exist from assumption 1 . It is clear that these departures may be of such magnitude as to have important implications for the use of these specific formulae and for the manner in which data on consanguinity effects are utilized for a variety of genetic calculations. Out of a multitude of possible illustrative models, two simple alternatives suggested by the present survey data may be considered. These alternatives are certainly abstractions in that, while they represent a step toward biological realities, they are still gross oversimplifications. Without these oversimplifications, however, the principal point could be buried in a mass of mathematical detail. Let us assume that in a group of 10,000 individuals there occurs a completely neutral and completely recessive gene. This gene is limited to three extended kindreds, in each of which 10 (heterozygous) members possess it. This group moves into a new and favorable geographical area. Circumstances are such that this group immediately becomes subdivided into three subgroups ("neighborhoods") comprising, respectively, 10, 20, and 70 per cent of the population, with differing rates of inbreeding and with no exchange of members. It may be assumed that at the time such a group first moves into an area and distributes itself to occupy the desirable portions of the new territory, biologically related individuals (kindreds) will tend to remain together. We will postulate that in the smallest group, 10 per cent of all marriages involve first cousins $(c=$ 0.10 ), while in the intermediate group the frequency of first-cousin marriage is 5 per cent, and in the largest group, 1 per cent. In time, all subgroups undergo a 100 -fold increase in numbers, so that the total population becomes $1,000,000$, with gene carriers increasing proportionately. No further mutations resulting in this particular gene occur, and there is assumed to be no genetic drift.

Let us now explore the consequences for the application of Dahlberg's formula of the location of the three kindreds carrying the hypothetical gene. We use Dahlberg's rather than Kimura's formula only because of the mathematical simplicity of the former. In model 1 , it is assumed that one of these kindreds finds a place in each of the three "neighborhoods." In model 2, it is assumed that all three kindreds come to reside in the largest "neighborhood." The differences which these accidents of distribution can introduce into estimates of $q$ as calculated from the over-all average of $c$ and $k$ are shown in Table IV. For each of the subpopulations, $k$ has been derived by substitution of the given values of $q$ and $c$ into Formula 1. Then, as would be the case in most attempts to calculate gene frequencies, an average value of $c$ and $k$ for the entire population has been obtained. It is apparent that the estimates of $q$ for the total population resulting from substitution of the average value of $c$ and $k$ in Formula 1 differ for the two models by a factor of 5 .

Although this particular example is undoubtedly somewhat extreme in the disparate degree of inbreeding in the subpopulations, as well as in the rarity of the gene concerned, and in the simplifying assumptions which are made regarding the characteristics of the population, it is clear that lesser disparities, such as can exist within even a single Japanese city (19), can easily result in

TABLE IV

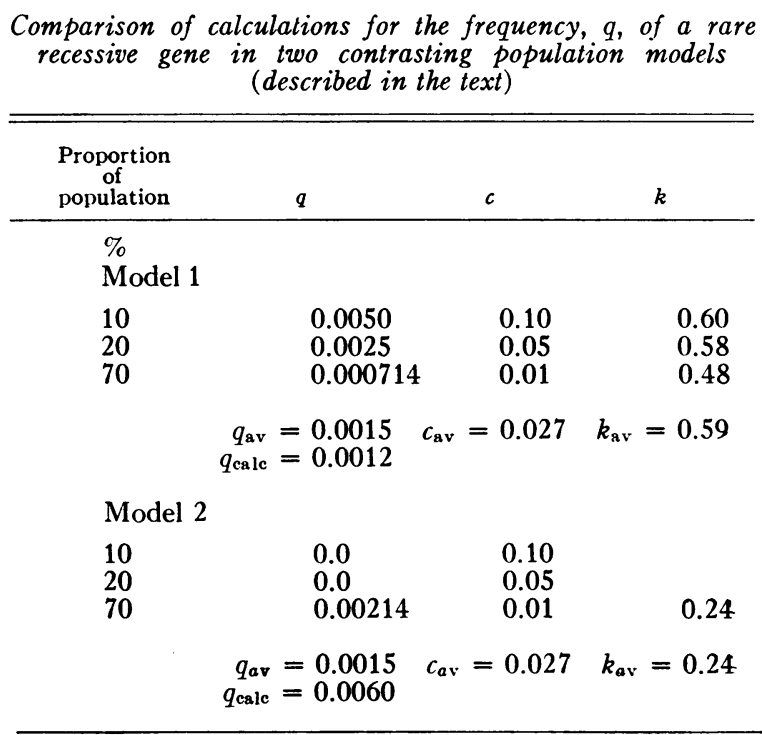


HAMILTON, NEEL, KOBARA AND OZAKI

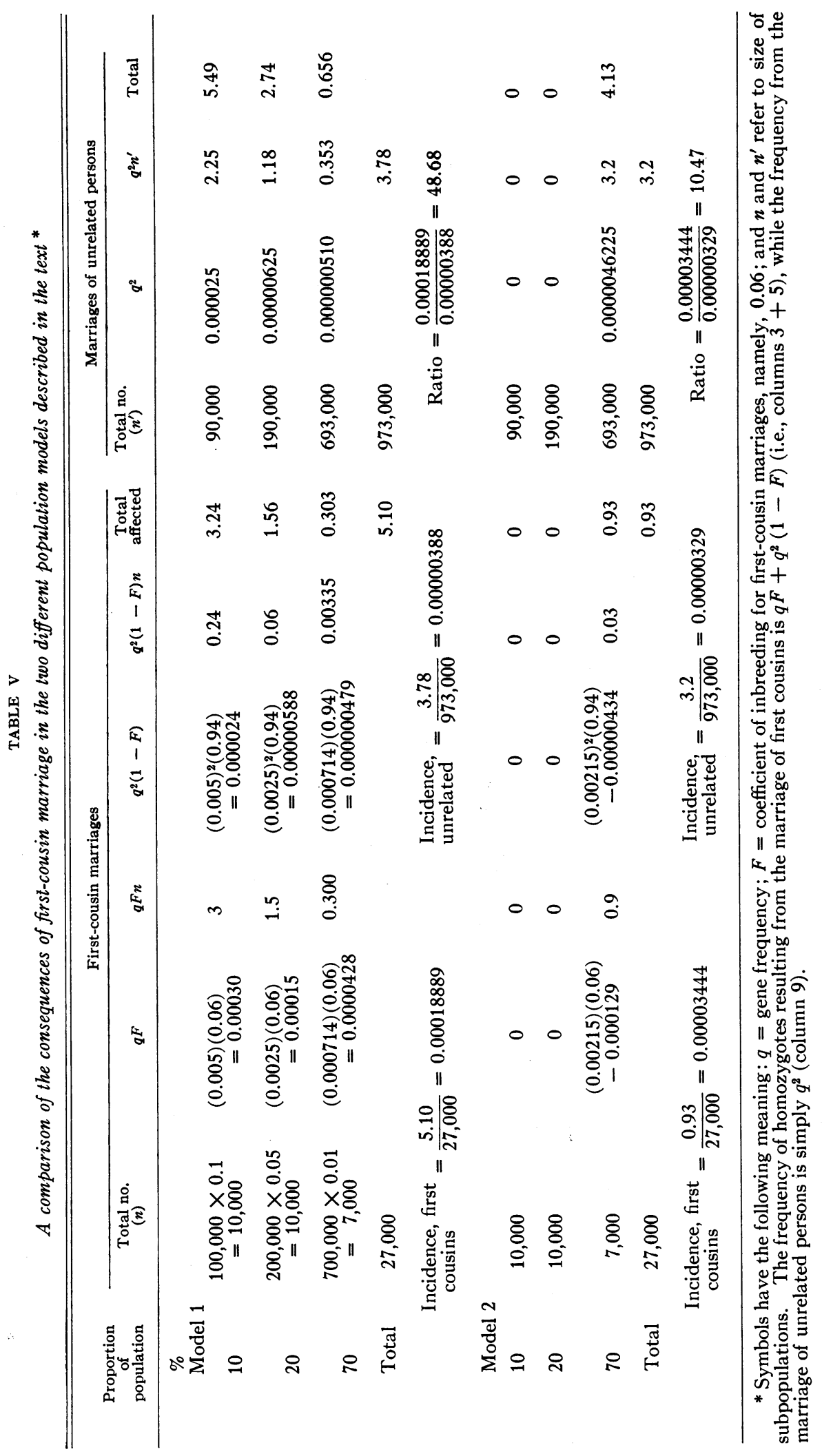


calculations differing by a factor of 2 or 3 . It should be re-emphasized that these are vastly oversimplified models, chosen from a multitude of possibilities, but a variety of other models would serve to make the same point of the influence of population structure on gene frequency estimates. Furthermore, only one of several ways in which populations may depart from the model has been considered here. Other possible, disturbing influences include such factors as fertility differentials, recent relaxation of inbreeding, and assortative mating. Fortunately, the increasing ability to detect a variety of heterozygous carrier states promises to substitute observation for the predictions of oversimplified statistical models, and at the same time may provide the insight to improve the models.

These simple models also have some interesting implications for attempts to utilize inbreeding effects for a variety of computations (23). Returning to the situation described above, assume that the trait associated with this hypothetical recessive gene is readily identifiable, so that it would be scored in studies on inbreeding effects. Further, assume only two types of marriages in the two populations, namely, between first cousins or between unrelated individuals, and, for this generation, stability in population numbers. The frequency of appearance of affected individuals from the two types of marriages in consequence of the two different models of population structure has been computed in Table V. In the first case, the ratio of proportion affected from first-cousin marriages to proportion affected from non-consanguineous marriages is approximately 49 , whereas in the second case, it is approximately 10 . Stated in terms of the ratio of the "inbred load" to the "randomly mating load" of Morton, Crow and Muller (23), these correspond to ratios of 763 and 151 , respectively.

The significance of a knowledge of population structure for attempts to calculate "mutation" versus "segregation" loads is thus obvious, but will not be discussed in detail at this time. However, it may be noted that this factor has been inadequately dealt with in some current treatments of the subject $(23,24)$. It should also be apparent from the model that conclusions regarding the number of loci at which recessive genes may occur with a given phenotypic effect (e.g., deaf mutism), which are based upon an apparent discrepancy between the observed frequency of the phenotype and the frequency of consanguinity among the parents of affected individuals, may also be biased by this "neighborhood effect." The bias can be of such a degree that, for the present, attempts on the basis of consanguinity data to estimate the number of recessive genes capable of producing a given phenotype, and the deductions drawn therefrom (25), cannot be taken very seriously, a fact which if not already apparent on theoretical grounds would be suggested by the wide discrepancy between calculations based on the data of Stevenson and Cheeseman (26) from Northern Ireland and Lindenov (27) from Denmark.

\section{SUM MARY}

A rapid and simple method for detection of hypocatalasemic heterozygotes for the gene responsible for acatalasemia is described. A total of 13,647 blood specimens from individuals residing in Hiroshima and Nagasaki has been examined in this manner, and the frequency of hypocatalasemics was found to be 0.09 per cent. Surveys in other parts of Japan have revealed frequencies of the order of 1.4 per cent. This unevenness in the distribution of a rare "recessive" gene, taken in conjunction with the known variation from locality to locality in the frequency of inbreeding, has important implications for the interpretation of data on inbreeding effects. Some of these implications are discussed.

\section{ACKNOWLEDGMENTS}

It is a pleasure to acknowledge the many ways in which Dr. S. Takahara of the Okayama University Medical School has been of assistance in this study. We are also indebted to Mr. H. Sadakane of the Department of Medical Sociology of the Atomic Bomb Casualty Commission for his aid in enlisting the cooperation of the families involved in this study. Drs. A. Kudô and W. J. Schull have been of invaluable assistance in certain aspects of this analysis.

\section{REFERENCES}

1. Takahara, S., and Miyamoto, H. Three cases of progressive oral gangrene due to lack of catalase in the blood. Nippon Jibi-Inkōka Gakkai Kaihō (in Japanese) 1948, 51, 163.

2. Nishimura, E. T., Hamilton, H. B., Kobara, T. Y., Takahara, S., Ogura, Y., and Doi, K. Carrier state in human acatalasemia. Science 1959, 130, 333. 
3. Takahara, S., Hamilton, H. B., Neel, J. V., Kobara, T. Y., Ogura, Y., and Nishimura, E. T. Hypocatalasemia : A new genetic carrier state. J. clin. Invest. 1960, 39, 610.

4. Beebe, G. W., Fujisawa, H., and Yamasaki, M. Adult Health Study. A. Selection of the sample. B. Characteristics of the sample. Atomic Bomb Casualty Commission, Technical Report 10-60. 1961, pp. v and 67.

5. Schull, W. J., and Neel, J. V. The health survey: A genetic study in Japan in Proceedings of the World Health Organization Seminar on the Use of Vital and Health Statistics for Genetic and Radiation Studies. In press.

6. Fisher, R. A. Statistical Methods for Research Workers, 11th ed. Edinburgh, Oliver \& Boyd, 1950.

7. Takahara, S. Acatalasemia. Naika Hōkan (in Japanese) 1961, 7, 488.

8. Kubota, Y., Fukuda, K., Ishihara, F., Furukawa, M., and Shiba, $Y$. On consanguineous marriage in the upper Ina valley. I. Over-all frequency. Minzoku Eisei 1950, 17, 114.

9. Schull, W. J. Empirical risks in consanguineous marriages: Sex ratio, malformation, and viability. Amer. J. hum. Genet. 1958, 10, 294.

10. Yata, H. A case of acatalasemia. Nihon Shika Hyoron (in Japanese) 1959, 204, 7.

11. Munro, N. G. Prehistoric Japan. Yokohama, 1908, pp. xvii and 705 .

12. Brinkley, F. A History of the Japanese People from the Earliest Times to the End of the Meiji Era. New York, Encyclopaedia Britannica, 1915.

13. Murdoch, J. A History of Japan. New York, Greenberg, 1903-1926, 3 vols.

14. Sansom, G. B. Japan: A Short Cultural History, rev. ed. New York, D. Appleton-Century, 1943.

15. Beardsley, R. K. Japan before history: A survey of the archaeological record. Far East. Quart. 1955, $14,317$.
16. Sjфgren, T. Die juvenile amaurotische Idiotie. Hereditas (Lund) 1931, 14, 197.

17. Dahlberg, G. On rare defects in human populations with particular regard to inbreeding and isolate effects. Proc. roy. Soc. Edinb. B 1938, 58, 213.

18. Neel, J. V., Kodani, M., Brewer, R., and Anderson, R. C. The incidence of consanguineous matings in Japan with remarks on the estimation of comparative gene frequencies and the expected rate of appearance of induced recessive mutations. Amer. J. hum. Genet. 1949, 1, 156.

19. Schull, W. J. A note on consanguineous marriages in the cities of Hiroshima and Nagasaki. Jap. J. hum. Genet. 1958, 3, 33.

20. Kimura, M. Theoretical basis for the study of inbreeding in man. Jap. J. hum. Genet. 1958, 3, 51.

21. Dahlberg, G. Mathematical Methods for Population Genetics. Basel, S. Karger, 1947.

22. Dunn, L. C. The effect of isolates on the frequency of a rare human gene. Proc. nat. Acad. Sci. (Wash.) 1947, 33, 359.

23. Morton, N. E., Crow, J. F., and Muller, H. J. An estimate of the mutational damage in man from data on consanguineous marriages. Proc. nat. Acad. Sci. (Wash.) 1956, 42, 855.

24. Morton, N. E. The mutational load due to detrimental genes in man. Amer. J. hum. Genet. 1960, 12, 348.

25. Chung, C. S., Robison, O. W., and Morton, N. E. A note on deaf mutism. Ann. hum. Genet. 1959, 23, 357.

26. Stevenson, A. C., and Cheeseman, E. A. Hereditary deaf mutism, with particular reference to Northern Ireland. Ann. hum. Genet. 1956, 20, 177.

27. Lindenov, $H$. The etiology of deaf-mutism with special reference to heredity in Opera ex Domo Biologiae Hereditariae Humanae Universitatis Hafniensis. Copenhagen, E. Munksgaard, 1945, vol. 8. 